Women's perspectives on liveability in vertical communities: A feminist materialist approach

Sacha Reid*, Kathy Lloyd and Wendy O’Brien

Department of Tourism, Sport and Hotel Management

Griffith University

171 Kessels Rd

Nathan QLD 4111

Australia

* Corresponding author: Email - s.reid@griffith.edu.au; Telephone - +61 737356559 


\title{
Women's perspectives on liveability in vertical communities: A feminist materialist approach
}

\begin{abstract}
Vertical communities are increasing as cities adopt compact planning approaches. However, the neoliberal urban development approach is often male dominated and reflective of male values and interests (Fainstein 2001). For women, changing demographic and societal trends linked to marriage, family and household composition, have led to increasing rates of female residential investment in and occupation of, high density developments. Little research has focused on this growing owner/occupier market. A qualitative approach framed with a material-discursive lens was used to explore women's perceptions of liveability and consumption of space within vertical communities. In-depth, semi-structured interviews with 25 females in South East Queensland, described experiences of liveability that were influenced by the materiality of apartments and buildings that created unsafe and inappropriate spaces for children as well as affective relations of distance rather than sociality. To avoid the problems plagued by high rise projects overseas and in Australia in earlier decades, a greater focus on women's needs should be considered in urban research and planning. Planners, developers and other professionals need to look beyond the investor driven stock currently provided to ensure sustainable and liveable housing options for this important emerging market.
\end{abstract}

Key Words: women, vertical communities, liveability, feminist materialism 


\section{Introduction}

Vertical communities, often in the form of high density residential and mixed use developments or multi-owned properties, are encroaching upon suburbs as cities adopt compact city planning approaches to deal with urban densification and population growth. However, the neoliberal urban development approach mobilised by developers, and associated professions including planning, architecture and finance, is often masculinised and focussed on economic imperatives. Kern and Wekerle (2008, 237) argue that "reliance on a small group of powerful decision-makers - the investors, developers, landowners, financiers and builders" has resulted in the forms and processes of redevelopment reflecting their interests and ideals. In addition, Fainstein (2001, 77) asserts that the industry "...is substantially male dominated and reflective of male values and interests.”

In Australia, this approach has led to the supply of speculatively led, investor oriented stock of one and two bedroom apartments (Easthope and Randolph 2009; Lloyd, Fullagar and Reid 2016). The gendered perspectives and needs of women, and children in particular, are often ostracised from the planning and development sectors, despite them being consumers of the residential spaces created. Flanagan $(1996,181)$ noted that "there remains so distinct a variation between groups of men and women on many urban issues that we must acknowledge the place of gender in assessing the urban environment and resolving its problems”. However, the literature reveals that only scant attention has been given to examining women's experiences of living and consuming within vertical communities.

This paper examines women's perceptions of liveability and consumption of space within vertical communities. A material-discursive approach using in-depth semi-structured interviews with 25 females in suburban Brisbane was undertaken. To avoid the problems plagued by high density residential developments overseas, and as a product of the 60s and 70s in Australia, there is a need for community engagement early in the planning process (Fischer and Aytruk 2011). Planning for vertical communities therefore must focus on integrating a mix of densities through both physical design and social sustainability strategies. Most importantly, the feminist views and experiences of vertical living need to be heard to enable for planning that better meets the liveability expectations of a diverse range of existing, and potential high density residents.

\section{Vertical Communities and Multi-owned Properties}

Australian population settlements have resulted in heavily urbanised centres, particularly along the eastern seaboard. Australian Bureau of Statistics (2013b) data suggests that there 
are approximately 1,056,236 flats, units or apartments with 1.93 million residents in Australia. However, these figures were based on census data collected over 5 years ago with the latest census only completed in September 2016. During this period, Australia has experienced significant growth in construction of multi-owned properties, namely one and two bedroom apartments (77.9\%) (ABS 2013c), with the majority rented (62.7\%) through the private rental market (79.4\% of all rented apartments) (i.e. direct with landlord or through real estate agent) (ABS 2013b). To date the economic imperative of obtaining sales contracts, aimed predominately at investors, appears to override the social and liveability needs of high density residents.

Changing demographic and social trends are also fostering growing urban populations. Individuals are marrying and starting families later, a segment traditionally seeking suburban detached housing. The growth of sole person or group households is another factor (Australian Bureau of Statistics (ABS) 2013a), as divorce, aging populations and investment in education influences housing choice. Furthermore, females are increasingly investing in their future, purchasing residential property, while aging populations are also driving the 'grey washing' of apartments as they downsize from large family properties in search of a low maintenance option and a more active and social lifestyle.

Today, urban densification, infill development and renewal comprise a key urban policy agenda for governments. However, Fincher $(2004,329)$ noted that developers are often limited by their own narratives and understandings of what is built i.e., "the imagination described in the narratives will enable the developers to build what they build, but it will also limit them to building what their narrative allows them to see”. This has widespread consequences for both those developing vertical communities, as well as those consuming these spaces. Two key narratives are driving the supply of vertical communities in Australia the young professionals and empty nesters (Costello 2005; Fincher 2004; Fullagar, Pavlidis, Reid and Lloyd 2013).

Although, not expressly creating housing product for women consumers within these categories “the developers' accounts separate into (1) the liberation of the empty nester mother from work in the home who may be tempted by the possibility of a high rise apartment... and (2) the treatment of the working woman, before she has had children" (Fincher 2004, 333). This perspective is reinforced by researchers such as Woolcock, Gleeson and Randolph (2010, 183) who note “...planners are planning for cities to accommodate singles, couples and the elderly", but not for those in other life-stages specifically families or children (Easthope and Tice 2011; Randolph 2006; Whitzman and 
Mizrachi 2012). As Whitzman and Mizrachi (2012, 234) stated "the needs of children and families have been virtually ignored" in the provision of vertical communities. As a consequence many apartment developments may not facilitate the needs of families or social spaces that accommodate these groups of consumers.

Whilst not necessarily targeting the needs of women, it has been noted that "fear for personal safety is an essential and pervasive element of urban life” for this group (Tacoli and Satterthwaite 2013, 3). Vertical communities have the potential to overcome this concern through security measures such as limited access to parking and living spaces. These design provisions create defensible spaces that seek to reinforce perceptions of safety and security, but may also reduce social interaction and community building and result in only surfacelevel relations between residents (Buys, Vine, and Miller 2013; Reid 2015). Yet, the inclusion of useable open spaces (preferably with barbeque facilities) was found to create a stronger sense of community within high-rise developments (Henderson-Wilson 2008). As Lloyd et al. (2016) observed, social interactions and sense of community are active contributors to an individual's perception of liveability within high density environments. Ultimately, the individual's perception of liveability is influenced by their personal situation and experiences, thus researchers must acknowledge these lens in their research approaches and analysis.

\section{A feminist material-discursive approach}

Within neo-liberal agendas, development discourses reflect a masculinist and corporatized vision of urban living that “actively makes invisible women's roles in the social productions of the household and the city” (Kern and Wekerle 2008, 247). For example, Fincher (2004) argues that despite developers expressing 'concern' for creating developments that attend to women's needs, traditional and patriarchal ideas reinforce gendered discourses surrounding home and family life. Rendered invisible through these discourses is how spaces within and around high rise developments reflect broader gendered discourses, with Parker (2011, 439) arguing research is required which considers the "material-discursive gendered dimensions of urban politics”. For example, Luxton (2015) argues that neo-liberal social policies have increased the care work that women manage in the home. Discourses of 'New momism", with its intensive child centered focus and relentless standards of perfection (Douglas and Michaels, 2004), affect how women manage social relations and spaces within high rise environments in ways that require exploration. In addition, fear and safety is used by developers to sell apartment living to women (Kern, 2010), both mothers and non-mothers, 
but risk, real or imagined works to affect how they move, interact and use space both within and around high rise developments.

Drawing on insights from new feminist materialism, we adopt an approach that acknowledges the spatial and structural dimensions (Parker 2011) of women's everyday accounts of living in high rise developments. Parker (2011, 441) argues that new feminist materialism provides the opportunity to examine how "biology, environment, urban restructuring, bodies, discourse, matter ... and space work together to shape different gendered" subjectivities. Within this approach, assemblages or relational networks are explored to examine how both animate (e.g., social interactions) and inanimate (e.g., social spaces) affect and are affected (DeLanda 2006; Deleuze and Guattari 1988). Assemblages can be constituted from a broad range of relations, such as developers, local government, body corporate regulations, residents, investment owners, with relations changing and in perpetual flux. Assemblages also work at a micro level, to include the mother-child assemblage, women and space assemblage or assemblages of dwelling. As Coole and Frost (2010, 27) point out this approach "foregrounds an appreciation of just what it means to exist as a material individual with biological needs yet inhabiting a world of natural and artificial objects, well-honed micro-powers of governmentality, but no less compelling effects of international economic structures." In this way we examine the affective flows in high rise spaces in which women live, their interactions with these non-human elements, as well as their everyday material relations that constitute women's lived experience in high rise developments.

\section{Research Methods}

To gain insight into the material relations and affective flows that work to shape living and consuming within vertical communities we framed our qualitative approach to explore the material discursive constitution of women's lives. Jackson and Mazzei (2012, ix) suggested that the research process involves thinking with the data to explore "something else" and that 'plugging in' theory with research data allows for an exploration of how the material and discursive, matter and meaning, interact. We therefore employed a materialist lens to explore the "intersection between things and people, between experiences and bodies" (Tuana 2008). We also examined the relational networks or assemblages that affected women's experiences of high rise living and how power relations materialise and the forces that worked in multiple ways to produce discourses of idealised high rise living. 
A two-stage purposive and snowball sampling approach to recruit participants was undertaken. First, the research was confined to suburban South-East Queensland in suburbs that are undergoing transition from predominately detached housing to higher density development. Suburbs were selected based on their current and proposed development trajectory. To ensure a range of perspectives, the suburbs chosen represented a geographic spread across the region. In total, six suburbs were included (i.e., Nundah, Chermside, Hamilton, Carindale, Kelvin Grove and Southport). Nundah and Chermside are located on the northside of Brisbane, approximately 10 kilometres from the Brisbane central business district (CBD), in a traditionally low density, working class suburbs that have undergone significant urban densification in recent years with apartment developments along key transit routes and around the regional shopping centre. Hamilton on the north-eastern reach of the Brisbane river, eight kilometres from the Brisbane CBD, has been transformed in recent years from industrial to residential apartments due to its premier location adjacent to the river and with city views. Kelvin Grove, located four kilometres from the Brisbane CBD is home to a University campus and near a major hospital, has also undergone significant urban densification and renewal over the last decade after state government ownership of the land was sold to developers. Carindale is home to another major regional shopping centre and is located on the south-east of Brisbane approximately 12 kilometres from the Brisbane CBD, a middle to upper class established suburb, the area around the shopping centre has experienced urban densification. Southport has been identified as a priority development area by the state government to advance economic development and urban renewal, and is a key regional suburb on the Gold Coast home to a mix of tourist, residential and commercial developments. Second, letters and postcards were distributed in random letterbox drops in these suburbs to introduce residents to the research.

The research specifically targeted privately owned buildings and not institutional, social or public housing. In addition, buildings were at least 12 months old and differed in terms of development size (medium-high density), apartment pricings and locations within each suburb. In total, 25 female residents who resided in nine different apartment developments agreed to take part in this study and were interviewed between September 2011 and September 2013. Each building provided parking on site, some public space in terms of gardens and a range of recreational amenities, although these differed in each case. Six of the nine apartment developments that the women lived within had swimming pools, a further one had a Jacuzzi. Internal shared recreational amenities were available although limited to lobby 
areas, small library, entertainment room, gymnasium and barbeque areas were evident in seven of the apartment complexes.

The semi-structured interviews provided a way to 'plug in' and to think with the research data. Questions included; What makes this suburb liveable? What do you like and/or dislike about living in your apartment? How often would you interact with other residents? Interviews were conducted at a time suitable for each respondent (e.g., during the day, early evening after work or on the weekend). Each respondent was given a pseudonym to protect their identity. Interviews were then transcribed verbatim, and rather than coding, our analysis was guided by our focus on how the material and discursive affected women's accounts of liveability. Jackson and Mazzei (2012, 2) argue that thinking with theory allows for “organizing and arranging” data to see how fields are connected. In reading and re-reading

the data we were attentive to how "women were positioned and positioned themselves ... as well as the material and social conditions” (Jackson and Mazzei 2012, 4) of their lives. Our approach examined the micro dynamics through which to map "the texture, the contradictions, the tensions and entanglements" (Jackson and Mazzei 2012, 12) that constitute women's everyday experiences of living in high rise environments. Our analysis identified three themes that represent the women's lived experiences of high-rise living in south-east Queensland.

\section{Research Findings}

\section{Liveability and Apartment Design}

High-density living environments were largely viewed by participants as suitable for singles or couples, but as materially inappropriate for women in terms of the provision of adequate space for families. Yvette for example, said while her family had enjoyed living in high rise, as her son became more mobile, the lack of space was restrictive and had the potential to create a sense of enclosure. This comment referred to inside the apartment and also the lack of easily accessible and useable space close to the high rise,

I don't know, but we are at a bit of a point of change in our lives with Finn growing up and obviously a very small space and living off the ground, not having access to a yard so we're actually. Up until now we haven't needed the space so...I haven't felt too closed in or anything but that's certainly starting to change. Little fellow, he's got lots of gear. We're lucky here because there is space, there's a bit of a yard downstairs but it's not very - there's not much shade and not much grass or anything so it's not that enticing to use that outdoor space. 
While there was some outdoor space, its size and appeal was limited and contact with the natural world was hot and lacking verdancy. Here, affective relations worked to produce reluctance on Yvette's part to be drawn towards the outdoor spaces as they failed to foster or create an environment where she and her son could enter and enjoy on a regular basis. Lack of play spaces for young children has also been linked to adverse mental health (Evans, Wells, and Moch 2003). Coupled with this, these relations of care are intensified through the materiality of smaller spaces to parent.

Another woman, Gloria, who enjoyed living in her apartment with her five year old son and husband, also felt the interior spaces of her building failed to provide adequate recreational areas for mothers and children. Firstly, while there was a swimming pool, it was not appropriate when the weather became cold. Secondly, Gloria would not allow her son to engage with the balcony as she feared he might climb up onto the balustrade and fall over. As a consequence their living space had become one of enclosure with the doors to the balcony closed most of the time. Gloria's affective relation to her living space had also become one of fear as her child became more mobile and inquisitive, "It's a bit scary for me because of the balcony". Thus, the outdoor space valued highly by most residents was problematic for this family. Even the large, good quality parks within a five minute walk of home, didn't attract Gloria as when “...it rained there was very little for children to do".

In contrast, the lack of spaces in which to enjoy social interaction with friends was an issue that impacted on Ruby's perception of liveability. Ruby felt the size of her apartment was not adequate for entertaining and this created tensions in her home.

Liveability is being able to have friends over and have barbecues. We can't do that where we live. We don't have any space on our very small balcony to have our barbecue. Our barbecue is in permanent storage in our lockup garage. That's sad. We have one person over in our little two bedroom unit, so that makes the three of us plus one visitor, our unit feels cramped. This is not liveable. We get stressed, we get irritable at each other, we get a little snappy at each other sometimes and I look around and I think I'm not actually mad at my family at all, it's actually we're cramped.

Thus, these assemblages of unit living, smaller spaces designed by architects and developers and promoted by discourses of urban development and consolidation, appeared to create a material existence that was impacting negatively on Ruby's sense of liveability. The lack of space again worked to turn women inwards into confining spaces that had the potential to affect their health and wellbeing. As Kern and Wekerle (2015) point out, the home is positioned as a commodity, rather than a space in which to live and interact. Ruby is confined 
by the design of her apartment which “... overlooks biological needs for space”. However, space is not an inanimate entity, but rather works in the assemblage of everyday living. Thus for mothers with young children, managing the emotion work within the family is intensified within the contained spaces of high rise (Strazdins and Broom, 2004). Therefore, the affective relation of fear and risk needed to be managed for themselves and those they were responsible for, potentially limiting their interaction with public space both within apartment developments.

This is where proximity to other amenities offered in the suburb becomes integral to the success of high-rise living. For example, Kate felt that she and her partner "could still do everything” even if they didn't have a car as "everything's within walking distance". However, as mentioned, movement is more difficult for women with children. Lack of green space in the areas within and surrounding high rise developments was particularly difficult for Ruby and her daughter as they were at home for most of the day. She described the effects of getting away from the building with her family,

We're suffocating in the concrete and we just want to see trees and grass and what's a horse look like, what's a sheep look like - start forgetting. We rarely get out of the city and when we do and we start seeing those things it's like wow and you feel this calmness come over you and remember that.

For Ruby, being able to access greenspace was not just recreation, but a mental health break. This brings to light an important issue for long term female residents who may have limited access to alternate environments for recreation and socialising.

\section{Social Interaction}

Relations within high rises were often vastly different from the visions of development assemblages. Rather than creating community or relations of connectivity, high-rise living was considered a space of social isolation by most respondents. The design of the carpark allowed residents to drive into the building, go up the lifts and straight into their units with little contact with the people living around them. Andrea discussed how the design of the building, was a non-human element that created relations of distance, rather than connection.

Most of the other people you don't know. It's funny, we live so close to each other, but you rarely - you know when I pull into the car park there's very rarely anyone else in there and you walk up here and you sort of might occasionally pass someone, but you're living quite close but you don't really see people that often to be honest. 
The spatial configuration of the apartments was a barrier to social connection and rather than creating intra-connections between the residents created spatial distances that restricted familiarity and threatened sociality.

Another spatial condition that affected the sociality and liveability of the high rise was the homogeneity of the units. Women suggested there was no way of knowing whether someone had a common interest/value that could be a starting point for a relationship and they were unable to make even casual connections. Kelly discussed the lack of social interaction.

I suppose isolated maybe but that again is probably because I haven't put in the effort to be part of the community to get to know people, to get involved. People, you see them come and go as they're coming home from work, going to work and I'm the same. You don't really - and when you're kind of three floors up it's not like you're standing in your front yard and they're walking past so you can have a quick chat. So you see them but you don't really get that connection and attraction.

Both Andrea and Kelly's comments highlight how assemblages of development can work to limit affective flows of intra connection between residents. Tina also noted that the scale of the development impacted on peoples "ability and motivation to approach and talk with other residents”. For example, medium density developments of up to four storeys and with smaller numbers of apartments were seen as facilitating more interaction between residents. Thus, despite living in close proximity to a large number of people, the focus on consumption of particular 'lifestyles' in high rise developments can create a sense of social isolation that has adverse consequences for mental health (Evans, Wells and Moch,2003).

However, there was also a preference expressed for light social relationships both in and outside of the building. Women did not necessarily want intense, close friendships with other residents because of issues with privacy. Others preferred their own company to being with others. Leah for example, enjoyed the privacy of high rise living "To be honest I actually quite like the privacy. People just respect your privacy and no one really interferes with your business. It is actually quite lovely". Sue was also more comfortable with life outside of the building due to her familiarity with the local coffee shops and the staff she had known for years. She particularly liked the idea that it "wasn't an in your face close knit community" but one she enjoyed being part of, when she felt like it before retreating back in to her apartment. These ideas of limiting social relationships are also important when considering women's sense of safety and security in and around high rise buildings. 


\section{Safety and Security}

Respondents indicated that they felt relatively safe in their high rise homes. For many women, living above street level was a benefit to high density living as their perception of privacy and safety was increased when they knew people could not see into their homes. Kelly for instance, commented how the safety assemblage in her building made it a virtual "Fort Knox. You can only get to your floor, with your floor keys, you can only get to your floor and the ground and the basement". Safety was a key affective relation that women articulated when describing high-density living. As Sandy noted "I feel very happy here, and very confident and very safe". Anita, an older respondent, also commented,

The family wanted me to come here for security, because they were worried about my being in the house because so many older people have been bashed and that sort of thing. It is very safe here and very secure.

The perception of security therefore gave many of the interviewed women, and their families, a sense of ease and confidence about their safety. Coupled with this, was the knowledge that they were in close proximity of neighbours. This was viewed by some as a positive, as they never felt alone, even if they were on their own. Andrea, could go to other residents if needed, "I know that if I was in trouble or something was going on or I felt funny, I could ring them and say, hey can I come over?”. Anita also experienced this when she suffered a health setback explaining how "the lady up the top floor, she said call me anytime and people are like that."

Developers facilitate the perception of safety and security through a range of material means. For example, intercom security, locks, car park access only for residents and access to the building from the locked car park, worked to provide a sense of spatial safety for women. Yet as Kern $(2011,3)$ argues, the restructuring of urban spaces draw on notions of women's "fear, vulnerability and the need for protection.” Women are thus positioned through relations of fear that 'sell' the safety of high rise living. However, as noted earlier these security measures may also result in a sense of social isolation. As Anita commented "you mostly meet them [others] either down in the foyer or in the car park. Maybe on our own floor, if we happen to go out into the hall and someone's there." Car parks are not the most conducive locations for social interaction, leaving many on edge or cautious.

Other on-site spaces can also increase the perception of risk for women. Common property areas are regularly sold as a benefit of high rise living as they are internal to the development and therefore somewhat exclusive. However, if these common spaces are 
misused or poorly maintained this can affect resident's perception of safety. Deborah's experience of the common recreation area in her development illustrates this point,

We've got a communal area on the seventh floor, it's a big balcony that's got a nice big barbeque and it's...got a nice spa pool on it, and it's got a sauna...The couple of times that I've been up to show people around, when I first moved in there, and looked at this - it was an absolute mess. People had used the barbeque, it was filthy, they'd left cigarette butts up there, they'd left beer bottles and it was just horrible. Honestly, I haven't been up on the seventh floor for ages...I just don't want to.

Thus, apart from the costs to the Body Corporate to maintain these common spaces and repair damage the perceived safety, and more broadly, liveability of the development may be compromised.

Relations of fear also arose for some in the areas surrounding high rise developments. Andrea, for example, had safety concerns over social changes in the suburb that prevented her from walking outside, "I love walking around the area and I don't - that's why I bought this [indoor exercise machine], because I don't do it anymore." Yvette, a mother with a small child, also found the area around her apartment building challenging to navigate and often unsafe, for other reasons. It was difficult for her to walk to local amenities whilst pushing a pram, "like traffic and with - there's really not very good - it's hard to cross the road and pushing a pram.” Perceptions of safety, and risk therefore, work to confine women, and their children (Warner, 2006), in the private spaces of the home. Thus, although new urban spaces are suggested to offer women freedom through consumption (Kern 2010), freedom and excitement sit in tension with fear and containment.

\section{Conclusion}

Fincher's (2004) research on high-rise developers in Melbourne problematized the gendered assumptions that lie behind development decisions. She noted that the views of the male dominated property development industry about women's housing choices at different stages of the life-course have serious effects on the kinds of projects produced and the social infrastructure that accompanies them. Over 10 years on, we have argued that despite evidence that women are now considered an important market for high rise developments, their needs are still largely ignored and their experiences of everyday citizenship within neo-liberal cities is commodified and gendered (Fincher 2004). Our research has highlighted that despite the 'imagined community' developers have built and marketed these buildings for, the profile of residents is far more diverse and their needs more complex. Of particular concern in this 
paper, was the lack of consideration given to how women use, manage and experience 'space' in (and around) high rise settings and how this affects their perceptions of liveability. The themes identified provide some insight in to the experience of high rise living for these women.

The size and design of apartments, was a particular issue for women with children. They felt limited in terms of what they could do in the space and where children could be allowed to play safely on their own. Outside space was also not conducive to play as the spaces were usually small and lacked sun protection. So for mothers, internal and external space had to be managed at all times. These traditional gendered roles are intensified through materiality of apartments, women's emotion work, and the management of risk to children. In addition, the potential to entertain in their apartments was limited as the balconies were deemed too small. Thus, apartment design was confining and anti-social, especially for those women with families or for those who wished to socialise and entertain within the home.

Opportunities to engage in social interaction with other residents were also limited partly by the design of the building but also by choice. For example, the buildings had little, if any, common space where people could gather for a small event or meet during their daily routines. Anonymity had to some degree been designed in to the building. Contact with other residents was infrequent and limited to, for example, short interactions in the car parks. However, the women did not express any real desire to mix with other residents which may suggest that their preferred 'community' was sought outside of the building.

A sense of personal safety and security was clearly a positive attribute of the high rise environment for these, and other, women (Tacoli and Satterthwaite, 2013). First the design of the building gave them confidence that once they entered, they would be safe. For example, the secure parking areas, lighting, and restricted entry to the building were seen to create a safe space. Interestingly in this case, the knowledge that neighbours were close also gave women a greater sense of safety and security. So although social interaction was not sought, the casual relationships in the building were enough to give women the confidence that neighbours would help if needed. However, lack of maintenance and misuse by other residents were key problems for women in terms of their confidence in using on-site facilities (e.g., pools and recreation areas). In addition, although women with children turned to the spaces outside of the development for recreation opportunities and access to green space that was lacking on site, the difficulties of getting to and from these sites created tensions for mothers in terms of safety and risk. 
Overall, the experiences of these women showed that high rise developments can deliver in terms of a sense of security and safety. However, design constraints in terms of size of apartments and poor management of on-site facilities limited the potential for recreation and social interaction, in particular for those women with children. Therefore, the development's proximity to amenities in the surrounding area was important to their sense of liveability. This suggests that the location of a development, the nearby amenities as well as the design and mix of apartments in the building are central to women's perceptions of liveability in high rise developments. Planners and developers must consider the full range of consumers who will be utilising and living within these spaces to ensure that they are creating liveable and desired high rise options for consumers. However, a challenge for the industry is determining how we can accommodate 'difference' in generic products, such as many apartment style buildings, when this difference incurs costs.

Finally, limitations abound in all research approaches and methods. We recognise that women's accounts are already a process or filter of something that has already been interpreted (Jackson and Mazzei 2012). However, we also contend that our approach "opens up ways of thinking and meaning” (Jackson and Mazzei 2012, 14) that provide useful insights into feminist materialist perspectives of high density living and which lay the foundation for further research to extend our understanding of this important field of study. For example, women's intentions to live in high-rise settings and their perceptions and understandings of this lifestyle at different points across the life span are largely unknown. Also, women with children are an important yet under-researched group that will require further investigation as traditional housing stock and affordability decreases. Finally, how the development industry considers, or otherwise, the needs and wants of women within the design and planning of high density environments requires elucidation.

\section{References}

Australian Bureau of Statistics 2013a. "B23 Relationship in Household by Age and Sex.” Retrieved from

http://stat.abs.gov.au/Index.aspx?DataSetCode=ABS_CENSUS2011_B32

Australian Bureau of Statistics 2013b. "B32 Tenure Type and Landlord Type by Dwelling Structure.” Retrieved from

http://stat.abs.gov.au/Index.aspx?DataSetCode=ABS_CENSUS2011_B32

Australian Bureau of Statistics 2013c. "B36 Dwelling Structure by Number of Bedrooms.” Retrieved from 
http://stat.abs.gov.au/Index.aspx?DataSetCode=ABS_CENSUS2011_B32

Buys, L., Vine, D. and Miller, E. 2013. "What makes inner city high density liveable? Insight from residents in Brisbane, Australia.” Environment Management and Sustainable Development, 2 (1), 14-33.

Coole, D. H. and Frost, S. 2010. New Materialisms: Ontology, Agency, and Politics. Durham NC: Duke University Press.

Costello, L. 2005. "From Prisons to Penthouses: The Changing Images of High-Rise Living in Melbourne.” Housing Studies, 20 (1), 49-62.

DeLanda, M. 2006. A New Philosophy of Society. London: Continuum.

Deleuze, G. and Guattari, F. 1988. A Thousand Plateaus. London: Athlone.

Douglas, S.J. and Michaels, M.W. 2004. The mommy myth: The idealization of motherhood and how it has undermined all women. New York, NY: Free Press.

Easthope, H. and Randolph, B. 2009. "Governing the compact city: the challenges of apartment living in Sydney, Australia.” Housing Studies, 24 (2): 243-259.

Easthope, H. and Tice, A. 2011. "Children in apartments: implications for the compact city.” Urban Policy and Research, 29 (4), 415-434.

Evans, G., Wells, N. and Moch, A. 2003. "Housing and Mental Health: A Review of the Evidence and a Methodological and Conceptual Critique.” Journal of Social Issues, 59 (3), 475-500.

Fainstein, S. 2001. The city builders: Property Development in New York and London 19802000 ( $2^{\text {nd }}$ ed.). Lawrence: University Press of Kansas.

Fincher, R. 2004. "Gender and Life Course in the Narratives of Melbourne's High-rise Housing Developers.” Australian Geographical Studies, 42 (3), 325-338.

Fischer, H. and Aytruk, G. 2011. Residential density (Liveable Communities): Market perceptions. Adelaide: Adelaide Thinkers in Residence Program.

Flanagan, M. 1996. “The city profitable, the city livable: Environmental policy, gender, and power in Chicago in the 1910s.” Journal of Urban History, 22, 163-189.

Fullagar, S., Pavlidis, A., Reid, S. and Lloyd, K. 2013. "Living it up in the 'new world city': High-rise development and the promise of liveability.” Annals of Leisure Research, 16 (4), 280-296.

Henderson-Wilson, C. 2008. "Inner city high-rise living: a catalyst for social exclusion and social connectedness?” Paper presented at the Australasian Housing Researchers' Conference 2008, Melbourne. 
Jackson, A. and Mazzei, L.A. 2012. Thinking with Theory in Qualitative Research: Viewing Data Across Multiple Perspectives. New York: Routledge.

Kern, L. 2010. “Selling the 'scary city': gendering, freedom, fear and condominium development in the neoliberal city.” Social \& Cultural Geography, 11 (3), 209-230.

Kern, L. 2011. Sex and the Revitalized City: Gender and Condominium Development and Urban Citizenship. Vancouver: UBC Press.

Kern, L. and Wekerle, G. 2008. “Gendered spaces of redevelopment: gendered politics of city building.” Gender in an Urban World (Research in Urban Sociology), 9, 233-262.

Lloyd, K., Fullagar, S. and Reid, S. 2016. "Where is the 'Social' in Constructions of 'Liveability'? Exploring Community, Social Interaction and Social Cohesion in Changing Urban Environments.” Urban Policy and Research, 1-15.

Luxton, M. 2015. "Feminist scholarship and family sociology: New ways of thinking, outstanding questions.” Canadian Review of Sociology, 52 (2), 212-221.

Parker, B. 2011. "Material Matters: Gender and the City.” Geography Compass, 5/6, 433447.

Randolph, B. 2006. "Delivering the compact city in Australia: current trends and future implications.” Urban Policy and Research, 24 (4), 473-490.

Reid, S. 2015. "Exploring social interactions and sense of community in multi-owned properties.” International Journal of Housing Markets and Analysis, 8 (4), 436-450.

Strazdins, L. and Broom, D. (2004). “Acts of love and work: Gender imbalance in emotional work and women’s psychological distress.” Journal of Family Issues, 25, 356-378.

Tacoli, C. and Satterthwaite, D. 2013. “Gender and urban change.” Urban Studies, 25 (1), 38.

Tuana, N. 2008. “Viscous Porosity: Witnessing Katrina”. In Material Feminisms, edited by S. Alaimo and S. Hekman, 188-213. Bloomington: Indiana University Press.

Warner, J. 2006. Perfect Madness: Motherhood in an Age of Anxiety. London: Vermillion

Whitzman, C. and Mizrachi, D. 2012. "Creating child-friendly high-rise environments: Beyond wastelands and glasshouses.” Urban Policy and Research, 30 (3), 233-249.

Woolcock, G., Gleeson, B. and Randolph, B. 2010. "Urban research and child-friendly cities: a new Australian outline.” Children’s Geographies, 8 (2), 177-192. 